\title{
Ellipsis
}

\section{Toxic Waste and a Side of Tartar Sauce}

\section{Cary Darbonne}

Follow this and additional works at: https://scholarworks.uno.edu/ellipsis

\section{Recommended Citation}

Darbonne, Cary (2016) "Toxic Waste and a Side of Tartar Sauce," Ellipsis: Vol. 43 , Article 4.

DOI: https://doi.org/10.46428/ejail.43.04

Available at: https://scholarworks.uno.edu/ellipsis/vol43/iss1/4

This Essay is brought to you for free and open access by the Department of English and Foreign Languages at ScholarWorks@UNO. It has been accepted for inclusion in Ellipsis by an authorized editor of ScholarWorks@UNO. For more information, please contact scholarworks@uno.edu. 


\title{
Toxic Waste and a Side of Tartar Sauce
}

\author{
Cary Darbonne
}

\author{
Ella V. Schwing Award Winner
}

After a long night of New Orleans debauchery, nothing on this planet satisfies me more than a fried shrimp po'boy (dressed, no tomato, with cheese, thank you). One bite and my hangover fades into distant memory. My pounding head and aching body are enveloped in a golden-fried haze. Even now, sober as a judge, typing these words makes my mouth water. Heaven. Recently, however, I had a conversation that made me think twice about my favorite recovery food. My friend Emily is what some people might call "crunchy." In other words, she's a vegan, composting, 100\% organic, hairy-pitted, environmentalist maniac. It all started one morning around 3:00 a.m. as we were stumbling through the Bywater, when all of a sudden the cravings hit me. The hunger...it had begun...I could think of nothing else but po'boy. "Cary," she said scoldingly, "I cannot believe you eat that crap. Don't you know its poison?" She then began the usual tirade, "Blah blah GMOs blah blah Monsanto blah blah overfishing blah pollution." I could barely hear her over the sounds of my stomach screaming for deep fried crustaceans and more whiskey, but something she said made me stop and think: "Don't you remember Fukushima? Really, our seafood is poisoned!"

Fukushima Daiichi was the name of the nuclear power plant that failed as a result of the massive earthquake and subsequent tsunami that occurred off of the northeastern coast of Japan on March 1 $1^{\text {th }}, 2011$. The combined force of these two natural disasters took the lives of over 18,000 people, and displaced thousands more, but the negative effects of the Fukushima meltdown are not as easily visualized (Oskin, "Japan Earthquake...”). I began to wonder if Emily was right. Is our seafood poisoned with radioactive waste? For the sake of the po'boy, I had to get answers.

It all began when the nearly 50 -foot tsunami hit Japan's Tohoku coast. Immediately, all of Fukushima's 11 operating nuclear reactors lost power, halting the nuclear fission process. Nuclear fission, (which generates nuclear energy,) occurs when high speed particles called neutrons strike uranium atoms, causing them to split in half. Inside each reactor, bundles of uranium fuel rods are immersed in a highly pressurized water tank. When the neutrons strike the rods, it releases a lot of energy, and consequently, more neutrons, which in turn split more uranium atoms in a massive chain reaction. The water in the tanks is heated by this energy and converted into steam, which is then used to drive turbines that produce electricity (Sample).

Although the nuclear fission process at Fukushima Daichii had been stopped by a loss of power, large amounts of heat were still released from the uranium fuel rods. Most of the reactors went into "cold shutdown" and were able to circulate the water needed to cool the output of heat, but the three oldest reactors were not able to regain power. 
Without the ability to cool itself, the water inside these pressurized vessels continued to heat rapidly and boil. This overheating damaged the highly radioactive uranium rods and the thick concrete shield that contained each reactor (Grimston). With no way to contain the breaches, contaminated waste slowly began to leak out into the Pacific Ocean, and unfortunately, it was only the beginning.

Employees of the Tokyo Electric Power Company (TEPCO), responsible for operating the plant, have been struggling nonstop to contain the multiple leaks, along with other sources of escaping radiation, for the past four years since the initial incident. In August of 2013, TEPCO woefully admitted that 300 tons (71,895 gallons) of radioactive water had been pouring into the Pacific Ocean every day, which is enough to fill an Olympic-sized swimming pool every eight days (Kiger). That amount may sound small compared to our vast and voluminous ocean, but over time, it adds up. Dr. Janette D. Sherman, M.D., a physician and toxicologist specializing in nuclear radiation, says that the situation is "so radioactive and unstable that it may never be contained...And now, four years after the Fukushima nuclear plant meltdown, radioactive materials continue to flow into the air and ocean. Given that it takes 10 half-lives for an isotope to completely decay...that will be nearly three centuries...in one lifetime our world has become a massive dumping ground" ("TV: Nuclear waste spilling...").

As of this month, radiation from the disaster has officially reached the North American coastline. Small amounts were first detected on Vancouver Island, British Columbia, but chemical oceanographer Ken Buesseler stresses that the levels are very low. He claims, "Even if the levels were twice as high, you could still swim in the ocean for six hours every day for a year and receive a dose more than a thousand times less than a single dental X-ray. While that's not zero, that's a very low risk" (Loew). In fact, current levels are about 1,000 times lower than the limit for drinking water set by the U.S. Environmental Protection Agency (Oskin, "Trace Amounts..."). Much to my surprise, the ocean has always contained small sources of naturally occurring radiation that often exceed the levels found in isotopes from Fukushima. These sources, such as sunken nuclear submarines and natural radiation from the earth's crust, apparently pose little risk to human health (Greger). That may be good and fine for a human being, but exactly what effect does the radiation have on the creatures that live in the ocean and immersed in its waters 24/7?

In my research, I found a lot of fear and speculation about the radiation levels in our seafood, but I wanted hard scientific facts. Pete Knutson has been a salmon fisherman for over 40 years, and sells his wares at farmer's markets around Seattle. After he watched multiple customers pass on his fish over fears of radiation, he coughed up the $\$ 1,200$ to test for radioactive isotopes in his product. Of the seven samples he sent to an internationally certified laboratory for testing, five came back without any detectable levels of radiation, and two samples showed readings several hundred times lower than the approved level for human consumption (Ahearn).

That was somewhat reassuring, but what about the area closest to the incident? Is it safe to eat any seafood in or from Japan? Scientists have recorded deadly levels of radiation in fish caught off the coast of Fukushima prefecture, and Black Sea bream are currently restricted from being fished in Japan due to radiation levels 124 times more 
than the safe threshold for consumption ("Fish testing at 124 times over..."). While that is only one species, it does not bode well for the others in the vicinity. According to the Woods Hole Oceanographic Institute and Center for Marine and Environmental

Radiation, most of the marine life that is contaminated with Fukushima radiation remains near Japan's coast, except for the far-ranging migratory species like the Bluefin tuna ("Educate Yourself"). Even still, University of Washington oceanographer Kim Martini says "to actually get a harmful dose of tuna you have to eat 2.5 tons of tuna a year," which could be difficult for anyone who isn't a great white shark (Urban).

It all comes back to the po'boy, though. What about the shrimp? Interestingly enough, one study shows that yes, there is a dangerous amount of radiation in our seafood, but it didn't come from Fukushima. Polonium, which is a radioactive byproduct of uranium decay, has entered our oceans due to its use in cigarette manufacturing. This study compared men's semen levels before and after a seafood meal and found that just one seafood meal resulted in a 300 percent spike in radioactive polonium levels in the semen. Although that is not enough to cause infertility, the repeated ingestion of seafood could very well put you at risk. Much to my shock and dismay, the study shows that there is eight times more polonium in cooked shrimp than in raw. This is believed to be because most of the polonium resides in the shrimp's internal organs, which is released when put into boiling water (Greger).

At this point in my research, I wish I would have stopped because what I read next really made my stomach turn. Ninety percent of the shrimp we eat in America is imported from international farms, and only $2 \%$ of that amount is inspected by the FDA. Of the amount inspected, many are sent back due to reports of "filth" and contamination from banned chemicals and pesticides. There are reports of shrimp being processed in facilities littered with garbage and flies, of shrimp being stored at warm temperatures, of shrimp packed in ice made from local Vietnamese tap water, which the government recommends you boil before drinking to avoid disease (Mercola). So, obviously, we have a little more to worry about than just radiation. There is a much bigger problem at hand.

Devastated, I shared with Emily what I found in my research. She seemed unfazed, "The 'man' wants you to keep buying seafood," she said while shaking her head, "It is a billion-dollar industry; they don't want you to be afraid." Moaning in anguish and grieving for lost ignorance, I wished I had never said a word to her. I was aware that the government occasionally may mask the truth to the population as a means to an end, and I cannot ignore the dozens of scientific reports from respected individuals that claim that the radioactive levels in our seafood have not exceeded approved levels for consumption, but there is definitely a cause for concern here. Even though I found no evidence that there is clear and present danger to our health from eating seafood after the Fukushima disaster, I do think that no radiation in our food is probably better for us than some. The situation must remain monitored, and more studies must be done on the long-term effects of ingesting contaminated seafood. In regard to my precious shrimp: I might not grow an extra limb from eating them, but I, unfortunately, cannot unlearn the revolting facts I uncovered. I'm not certain if I can ever look at a po'boy the same way again, even with my whiskey goggles on. For now, I'm forced to say a sorrowful goodbye. 


\section{Works Cited}

Ahearn, Ashley. "Scientists Say Stop Worrying About Fukushima Radioactivity in Fish.” opb.com. Oregon Public Broadcasting, 15 Jan. 2014. Web. 22 Apr. 2015.

"Educate Yourself." ourradioactiveocean.org. Center for Marine and Environmental

Radiation, Woods Hole Oceanographic Institution, n.d. Web. 22 Apr. 2015.

"Fish testing at 124 times over radiation limit caught off Fukushima." $R T$.

Autonomous Nonprofit Organization "TV-Novosti”, 13 Jan. 2014. Web. 2 May

2015.

Greger, Michael, M.D. "Fukushima Radiation and Seafood." Nutritionfacts.org. Nutritionfacts.org, 11 Feb. 2014. Web. 2 May 2015.

Grimston, Malcolm. "Fukushima: What happened - and what needs to be done." $B B C$. BBC, 11 Apr. 2011. Web. 22 Apr. 2015.

Kiger, Patrick J. "Fukushima's Radioactive Water Leak: What You Should Know." National Geographic News. National Geographic Society, 9 Aug. 2013. Web. 22 Apr. 2015.

Loew, Tracy. "Fukushima radiation has reached North American shores." Statesman Journal. Statesman Journal, a division of Gannett Satellite Information Network, Inc., 6 Apr. 2015. Web. 22 Apr. 2015.

Mercola, Dr. Joseph. "The Unsavory Aspects of Farmed Shrimp.” Mercola.com. Dr. Joseph Mercola, 14 Aug. 2013. Web. 4 May 2015.

Oskin, Becky. "Japan Earthquake \& Tsunami of 2011: Facts and Information." livescience.com. Live Science, 22 Aug. 2013. Web. 22 Apr. 2015.

---. "Trace Amounts of Fukushima Radiation Turn Up in Canada." livescience.com. Live Science, 7 Apr. 2015. Web. 2 May 2015.

"Pumps at Fukushima plant halted, toxic water leaking into ocean - TEPCO." $R T$. Autonomous Nonprofit Organization "TV-Novosti”, 21 Apr. 2015. Web. 22 Apr. 2015.

Sample, Ian. "Beginner's guide: How nuclear power works." The Guardian. Guardian News and Media Limited, 30 Apr. 2008. Web. 22 Apr. 2015.

"TV: Nuclear waste spilling into Pacific Ocean after power outage hits Fukushima plant." enenews.com. ENEnews LLC., 21 Apr. 2015. Web. 22 Apr. 2015.

Urban, Shilo. "Eating Fish After Fukushima: Is It Safe?" Organic Authority. Organic Authority LLC., 25 Mar. 2014. Web. 22 Apr. 2015. 